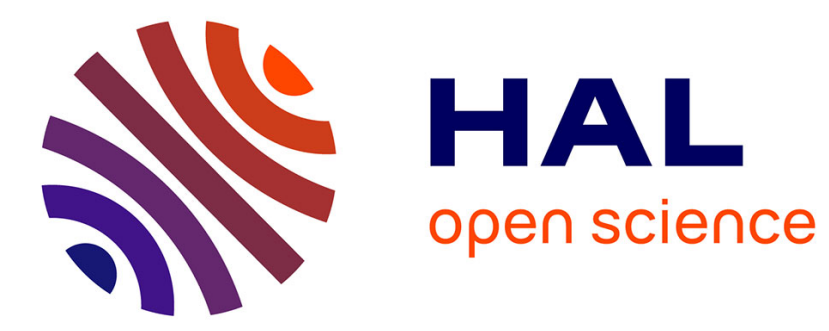

\title{
On the Cosmopolitics of Astronomy in Nineteenth-Century Paris
}

David Aubin

\section{To cite this version:}

David Aubin. On the Cosmopolitics of Astronomy in Nineteenth-Century Paris. Astro-Morphomata: Sternenwissen und Weltbürgertum in Medien und Kultur, Nov 2011, Cologne, Germany. hal00741449

\section{HAL Id: hal-00741449 https://hal.sorbonne-universite.fr/hal-00741449}

Submitted on 12 Oct 2012

HAL is a multi-disciplinary open access archive for the deposit and dissemination of scientific research documents, whether they are published or not. The documents may come from teaching and research institutions in France or abroad, or from public or private research centers.
L'archive ouverte pluridisciplinaire HAL, est destinée au dépôt et à la diffusion de documents scientifiques de niveau recherche, publiés ou non, émanant des établissements d'enseignement et de recherche français ou étrangers, des laboratoires publics ou privés. 


\title{
On the Cosmopolitics of Astronomy in Nineteenth-Century Paris
}

\author{
David Aubin \\ david.aubin@upmc.fr \\ Sorbonne Université / Pierre et Marie Curie \\ Institut de mathématiques de Jussieu \\ Histoire des sciences mathématiques \\ 4 place Jussieu 75252 Paris Cedex 05 FRANCE
}

Proceedings of the conference

"Astro-Morphomata: Sternenwissen und Weltbürgertum in Medien und Kultur" (18-19 November 2011), ed. Sonja Neef.

Morphomata series, ed. Prof. Boschung and Prof. Blamberger. Fink Verlag in Munich/Paderborn (Germany).

\section{Abstract:}

During the French Revolution, French astronomy was both contested by the Parisian mob, when Cassini was housted from the Observatoire, and courted by political power. The establishment of the Bureau des Longitudes, the expeditions for determining the length of the meter as well as the reliance of Napoleon on observatory techniques on the battlefield show that astronomy was quickly becoming an important auxiliary to the modern State. In the decades that followed, astronomical research was completely restructured by the State. At the same time, atheist narratives about the origins of the Solar system were first suggested and slowly gained credence. In this talk, I would like to use the case of Paris to explore ways in which we can understand the rise of the observatory sciences in the nineteenth century as a cosmopolitical project designed for displacing the basis of political authority from God to the people without falling into anarchy.

\section{Introduction: cosmopolitanism in astronomy and conflicts}

"Astronomy is the science of the cosmopolitan," wrote the Zurich erudite Gaspard Hirzel (1785-1823) in a book published in French and titled Astronomie de l'amateur (Hirzel 1820, 
x). With the term "cosmopolite," Hirzel wished to convey that the study of astronomy was worthy of any thinking being whatever was "the place in the universe where he live[d]." But Hirzel was well aware that his use of words was controversial: the cosmopolitan he had in mind had nothing to do with the "coward" who professed equal love to all the peoples of the earth only to camouflage his treachery toward his native country. No, Hirzel's cosmopolitan was literally an inhabitant of the cosmos without regards to the heavenly body he or she called home. Astronomy was slightly modified by every observer who had to take his or her own point of view into account, but it nonetheless remained the same science independently of all and everything. Everywhere different, astronomy was nothing but "universal" in the strictest sense of the word. ${ }^{1}$

Affirming the universality of astronomy, Hirzel acknowledged that this science had been unevenly pursued in various countries and times. Recent developments however seemed to favor cooperation among European nations. ${ }^{2}$ In Hirzel's view, cosmopolitan astronomy appeared as a pacified field of science where progress was pursued by an international community of scientists. Barely five years after the Napoleonic wars had caused havoc on European soil, astronomical research prefigured peaceful international collaborations on wider scales.

Hirzel's work, moreover, was directed at amateurs "of one sex or of the other" who had little mathematical knowledge. Ignorance of spherical trigonometry or mathematical analysis did not preclude one to get a clear view of what took place in the heavens. ${ }^{3}$ Even those who had to forego any attempt at scientifically understanding astronomy could be enlightened by its "moral and religious" aspects (Hirzel 1820, xvi \& xx). Hirzel's cosmopolitan astronomy indeed was an irenic vision of science. The true knowledge of the cosmos, he claimed, was achieved by peaceful cooperation and it was accessible to all.

The appeased world of science described by Hirzel stands in strong contrast with the violence of the debates to which the pursuit of astronomy often gave rise in the nineteenth century. In 1900, the mathematician Joseph Bertrand wrote about the exchanges between two Parisian astronomers in the 1860s [Le Verrier and Delaunay]:

When, a hundred years after D'Alembert's death, his correspondence with Lagrange was published, it was necessary to replace a few niceties associated by negligence with the name of some of his colleagues whom he disliked. In the official and private

\footnotetext{
${ }^{1}$ Note that Alexander von Humboldt had not yet decided, then, to make use of the term "cosmos" in order to describe the universe.

2 "jamais époque plus glorieuse ne s'est annoncée pour l'astronomie, et dans ce moment même les savans [...] font de louables efforts pour l'avancer par la réunion de leurs moyens, et pour resserrer les liens, qui devroient unir les savans de toutes les nations, et de tous les pays du monde. Déjà [les] anciens rivaux, changé en de nobles émules, réunissant leurs vues et leurs talens, travaillent à la solution des mêmes questions, et cherchent par des voies différentes à atteindre le même but et de semblables résultats" (Hirzel 1820, xiii-xiv).

${ }^{3}$ On the relationship between mathematics and popularization, see (Aubin 2009).
} 
correspondences exchanged then [that is, at the time of the controversy between Delaunay and Le Verrier], if there are one day published, this is not too free a vocabulary, but whole pages that will have to be replaced by dots. ${ }^{4}$

This type of unseemly behavior often is the result of fights over power. In this paper, I would like to discuss what was at stake in the political history of astronomy in nineteenth-century Paris. Ideally, I would want to consider two parallel stories and offer some thoughts about the reasons why and how they should be considered together. The two stories I have in mind concern the relationship between astronomy and politics, on the one hand, at the time when absolutist monarchy was contested and ways to give at least some power to the people were being worked out, and, on the other hand, the emergence and diffusion of atheist or agnostic cosmologies in nineteenth-century Europe. The time period I would try to cover is the "long" nineteenth century from 1780 to 1914 . But I obviously cannot be expected to cover so much ground in a short paper. What I will do instead is focus on four episodes concerning the history of astronomy in Paris.

Before I turn to this, let me make a few introductory comments. Gods, stars and governments have been tightly linked throughout human history. But the long nineteenth century in Europe was the seat of a profound anthropological shift. In that period, the belief in a cosmos created and ordered by God was not only challenged by some scholars in the elite, but it became widespread belief in the French population that the Universe exhibited first and foremost a materialistic order that was by and large independent from the God idea. This momentous shift, I claim, is intimately linked with the development of representative democracy and, as Walter Benjamin clearly saw in his Passagenwerk, Paris was one of its epicenters. The violence of the political debates among astronomers was a reflection of the high stakes indeed involved in the process of deciding who was going to be allowed to speak for the heavens. ${ }^{5}$

Up to now, historians have focused on the history of nineteenth-century astronomy mostly from the perspective of scientific and instrumental developments. The internal organization of astronomical research has drawn much attention. Recently, Charlotte Bigg, H. Otto Sibum and I edited a collection of case studies titled The Heavens on Earth. In this volume, we argued that the rise and fall of astronomy as a central science (leaving natural history and medicine altogether aside) in the nations of the Western hemisphere was linked to the services it rendered to the State (Aubin, Bigg et Sibum 2010). By this we meant that those countries set up a very extensive network of richly-endowed observatories at a time when other scientific research institutions were seldom funded to the same level by the state.

\footnotetext{
${ }^{4}$ "Lorsque, cent ans après la mort de d'Alembert, on publia sa correspondance avec Lagrange, il fallut remplacer par des points quelques joyeusetés un peu libres négligemment associées aux noms de confrères qu'il $n^{\prime}$ aimait pas. Dans les correspondances officielles et privées échangées alors, si on les publie un jour, ce n'est pas un vocabulaire trop libre, mais des pages tout entières qu'il faudra remplacer par des points " (Bertrand 1900, 120).

${ }^{5}$ For a contrasted study of who claimed to be allowed to speak for the heavens in two very different countries in the 1860s, see my paper "Eclipse Politics in France and Thailand, 1868," in (Aubin, Bigg et Sibum 2010).
} 
The observatory saw the development of a coherent set of scientific techniques we have called "observatory techniques" which were used in a variety of scientific disciplines, like physics, mathematics, statistics, meteorology, geodesy, and so on. Observatory techniques played a crucial part in enabling the European colonial domination of the world, as well as the participation of a wider public in the metropolis to the scientific enterprise. Observatory techniques, in short, structured an epistemological domain at the same time as its wide impact upon the world. Already by the end of the nineteenth century, the coherence of the observatory sciences was breaking apart: physical and chemical laboratories were lavishly funded by the state; observatories became more en more specialized in positional astronomy, astrophysics, meteorology, etc., each domain at the expanse of the other. As a coherent locus for a representation of science and its impact on the wider world, the observatory had played out much of its earlier significance.

By that time, the aftershocks of the French Revolution were also dying out. It is a cliché to say that French Revolution was a political rupture in Western Europe, which building up on ideas developed by the philosophes of the Enlightenment completely upturned the order of the Old Regime. Historians as different in their perspectives as François Furet and Arno Mayer have shown that the change in the socio-political order brought about by the events of 1789 was worked out over the whole of the next century, if not longer. Now, from the anthropological perspective that I wish to develop, we may assume that any socio-political order has to be, if not based on, at least consistent with, a higher order which is cosmic. In this sense, the fact that a Bourgeois society based on however imperfect democratic principles was able to take roots in the Western world over the nineteenth century must be linked with the emergence, development, and diffusion of an atheistic cosmos. In other words, to establish a durable democracy, not only kings needed to be ousted from their palaces (or at least stripped of much of their power) but also God (or gods) from the heavens.

The notion that the cosmic and the social orders have a profound link with one another is very old indeed, but it was nicely brought to the fore and analyzed by the French anthropologist Maurice Godelier. Studying the Baruya people in Papua New Guinea, a tribe that was "discovered" only in the 1950s and "pacified" in 1960, Godelier was struck by the series of representations and practices instituting the violent domination of adult males on females and younger males which he established was the foundation of their society and modes of thinking. Godelier was able to study the way in which this society was constituted two or three centuries ago by the aggregation of several tribes. He paid great attention to the social rituals that had made possible to establish the Baruya society and keep it alive. In the anthropologist's classical manner, Godelier described in great details initiation rituals, sexuality, gender dynamics, and kinship structures, as well as the economy of giving and keeping identifying the key role of certain sacred objects in this society. "The social relations that allowed the Baruya to constitute themselves as a new society, and then insured its reproduction up to our days," Godelier concluded, "were of political-religious order. ... This 
is not only a society that is reproducing itself, but at the same time a cosmic order that is made manifest and brings its support to human enterprises. The social order is inscribed in a cosmic order" (Godelier 2007, 199). Of course, nineteenth-century French society was immensely more complex than Baruya society, if only because it had a much bigger population. But it faced very similar problems. Both the Genesis and Plato's Timaeus required the intercession of a creator. What cosmic order could replace the old one?

I believe that to adopt the anthropological view from afar is enlightening in order to understand better the way in which cosmologies were reinvented and popularized in the nineteenth century. As new foundations for social order were being sought after by various regimes, so were ways for construing the cosmic order explored in wholly new directions. To reconstitute itself as a new society, France needed to build a cosmic order that was congruent with the ideals it now proclaimed as the foundations of the social order. The most important of these ideals was the fact that every citizen should partake in the new order.

Let us now turn to my four little stories, which I conceive as social "astro-morphomata," that is, narrative accretions of important issues in the process of being worked out concerning the relationship between the social and cosmic orders.

\section{Revolutions at the Paris Observatory: Scientists in and out of Power}

On July 16, 1789, two days after the storming of the Bastille, an unruly crowd invaded the Paris Observatory. Why was the scientific monument attacked? According to all accounts, the astronomical purpose of the Observatory, or its royal status for that matter, had little to do with this. The crowd was merely looking to flour, arms, and powder which they believed might have been hidden in the Observatory or its famously deep and extended underground network. Nothing in this event, at first glance, seems to be related to observatory politics.

It is interesting to remember, however, that the day before, on 15 July 1789, an astronomer was elected mayor of Paris. A member of several academies and a prolific author, JeanSylvain Bailly (1736-1793) was already an influent member of the National Assembly. On 20 June, he had president the famous session known as the "serment du Jeu de Paume," whereby deputies swore to resist the king's wish to disband them and to stay assembled as the representatives of the people. Again, it is doubtful that we may establish a connection between the storming of the Observatory and Bailly's election as mayor of Paris, but this goes into showing that astronomers and astronomical institutions were interestingly involved during this eventful month.

In the 1780s, astronomy was a lively but contested territory in Paris. Perhaps the most conspicuous place devoted to astronomy, the Paris Observatory under the Cassini dynasty hardly seemed in position to pursue astronomical research in an efficient way. In his famous Tableau de Paris, Louis-Sébastien Mercier wrote of it: "Here is an observatory without a telescope; I see an arsenal without weapons." ${ }^{6}$ When César-François Cassini de Thury had

\footnotetext{
${ }^{6}$ « Voici un observatoire sans télescope : je vois un arsenal sans armes. » (Mercier 1789, vol. 10, p. 197).
} 
died from smallpox on 4 September 1784, it only seemed natural that his son, JeanDominique Cassini de Thury, take his position at the head of the Paris Observatory. Cassini de Thury had received the title of General Director of the Observatory by Louis XV in 1771 through a decree that specified that this position was hereditary. ${ }^{7}$ Few people objected at the time; other astronomers of the Academy possessed their own observatories which were often much better equipped than the Royal Observatory which by and large mostly served as a prestigious residence for some of the oldest academicians. In 1784, Cassini IV, as he came to be known, was just 36 years old, but already adjunct-astronomer of the French Royal Academy of Sciences since 1770. For some time already, he was filling in for his sickened father and had drafted an ambitious plan for revamping the Observatory, which hasd been submitted to the king. After some delay, important work was undertaken at the Observatory and its instrumentation was modernized. ${ }^{8}$

With the king's money, Cassini had been able to hire three students who would later rebel against his authority. Hired in 1782, the abbé Nicolas-Antoine Nouet (1740-1811) also served as the chaplain of the observatory were he said masses for Cassini and his family. ${ }^{9}$ The son of a navy officer Jean Perny de Villeneuve (1765-?) was hired in 1785 . He published his own Almanac in 1791, where he wrote: "Science followers will take pleasure in seeing that in the midst of the convulsions that were shaking France [...] long and painful work was carried out in the silence of the night [...]." ${ }^{10}$ Perny de Villeunve shared a little house with Nouet. Alexandre Ruelle (1756- ?), finally, was a deserter who took refuge in the observatory in 1785, where a family member lived, a clockmaker named Boucher.

But the landscape of Parisian astronomy was as complex as it was lively at the time (Hahn 1986). To quote Mercier again: "The observatory is in ruins \& astronomical observations are made everywhere but at the observatory." ${ }^{11}$ Even if the efforts made by Cassini to revamp the Royal Observatory had paid, the position of this institution was far from hegemonic. In the fourth volume of Montucla's Histoire des mathématiques, written by the astronomer

\footnotetext{
${ }^{7}$ The king wished that: "vu les travaux qui ont illustré les Cassini, et que par les connaissances profondes que le fils a acquises en astronomie, il est déjà émule de son père et digne de la plus haute protection de ses ayeux, la place de Directeur soit conservée dans sa famille" (S.-Devic 1851, 45). In his authoritative history of the Observatory, Charles Wolf however found no explicit mention of the hereditary nature of the title except in contemporary newspapers (Wolf 1902, 232).

${ }^{8}$ On the history of the Paris Observatory and Cassini at the end of the eighteenth century, see (Cassini 1810, S.Devic 1851, Wolf 1902).

${ }^{9}$ In 1799, Nouet will be one of the oldest savants to take part in the expedition in Egypt, where he had to good fortune to retain his instruments contrary to many of his colleagues and carry out a great deal of astronomical observations. He later worked for the War ministry, in particular on the cartography of the Mont Blanc.

10 "Les amateurs des sciences verront avec plaisir qu'au milieu des convulsions qui agitoient la France, et des grands intérêts qui partageoit l'esprit et l'attention de tous les citoyens, un travail long et pénible s'exécutoit dans le silence des nuits, et préparoit aux Astronomes à venir un secours destiné à durer autant que la révolution qui s'opéroit en même temps" (Perny 1791, p. 95).

${ }^{11}$ L'observatoire tombe en ruine, \& les observations astronomiques se font partout ailleurs qu'à l'observatoire" (Mercier 1789, vol. 10, p. 197).
} 
Jérôme Lalande (1732-1807), one finds a list of eleven active observatories in the French capital other than the monumental Observatory (Montucla 1802). ${ }^{12}$

To reaffirm the prominence of the Royal Observatory, Cassini relied more than ever before on the central power, that is, on the king and his ministers. With the political changes brought about by the Revolution, the Royal Observatory therefore was sure to come under severe attack. It has been shown that the changes of this decade were quite important to install the Paris Observatory as the main center for astronomy in the capital (Chapin 1990). But to Cassini himself, the change was not quite as beneficial; in fact, it was catastrophic! He was contested in the Observatory, jailed, escaped death by very little, and never recovered his position in the Parisian landscape of the observatory sciences, at a time when they became increasingly important as servants of the State. The way in which Cassini's power was contested in the Observatory has been told recently in the context of the rise of the sans-culotte figure (Burstin 2005).

The conflict that opposed Cassini to his assistants was a small replica of the general conflict between aristocratic elites and revolutionaries. In the first years of the Revolution, astronomy itself was subject to the process of "sans-culottization" as a book published then proclaimed.

I know that Astronomers and Physicists have repeated, following an Ancient, in all their prefaces, let no one enter without knowing mathematics; but this interdiction is to my eyes a vain etiquette introduced by pride and respected by ignorance. Our cidevant lords also used to say: let no one be admitted in our company without having shown their nobility titles. ${ }^{13}$

To recount day-to-day events regarding the failed attempt to "sans-culottize" the Observatory would lead us astray (Cassini 1810, S.-Devic 1851, Chapin 1990, Burstin 2005). But it suffices here to recall that these events had significant effects on the organization of astronomical research in Paris and in France. On 31 August 1792, in a session presided by Maximilien Robespierre, the Convention decided, following the suggestion of Joseph Lakanal from the Comité de l'instruction publique, to change the statutes of the Observatory:

Citizens, there is next to you a famous establishment where command is still exerted in the name of kings. We wish not to ask for its destruction: numerous books of astronomical and meteorological observations [...] speak for its usefulness. We ask

\footnotetext{
${ }^{12}$ See also (Gautier 1825, Hahn 1986).

${ }^{13}$ " Je sais que les Astronomes et les Physiciens ont répété, d'après un ancien, dans toutes les préfaces, que nul n'entre ici sans savoir les mathématiques ; mais cette défense n'est à mes yeux qu'une vaine étiquette, introduite par l'orgueil et respectée par l'ignorance. Nos ci-devants seigneurs disaient aussi : que nul ne soit admis à notre société, sans avoir montré ses lettres de noblesse » (Decremps 1792, 22).
} 
that Republican forms be imprinted on this monument and that the eternal laws of equality be substituted to whimsical power. ${ }^{14}$

Lakanal suggested that the Observatory be named the Observatoire de la République and that the four astronomers attached to it be treated equally. Of course, Cassini would have none of this and he resigned on 5 September 1793, to be replaced by Alexis Bouvard. But this was not the end of Cassini's misfortunes. Arrested on 13 February 1794, he was freed only after Rosbespierre's fall.

Cassini was not alone among astronomers suffer to from the Revolution. In his "History of Astronomy" for 1794, Lalande listed the astronomers who died during the Terror: Jean Sylvain Bailly who was beheaded on 12 November 1793; President Jean Baptiste Gaspard Bochart de Saron; Jean-Guillaume Wallot who died on 9 Thermidor (27 July), the day before Robespierre's fall, at age 51; Achille-Pierre Dionis du Séjour born in 1734 who died of a fever "made more dangerous by the worries of the time" (Lalande 1795)... During the Terror, it is said that Lalande had saved the life of several people by hiding tem in observatories. After 10 August 1792, he gave haven to Dupont de Nemours in the Observatory of the Collège Mazarin. The historian Garnier and a few priests after the "massacre de l'Abbaye" in September 1792 passed for astronomers at the Royal Observatory (Gautier 1825, 202-203).

After Robespierre's fall, however, the French State started to cover its astronomers with attention. Astronomers had played crucial roles in the establishment of the metric system, some of them being sent away where their telescopes to visit cities where unrest was causing many to see spies everywhere (Alder 2002). The Observatory had been explicitly mentioned in the law establishing the Republican year (starting the day if the fall equinox at the Observatory of Paris). On 25 July 1795, the Bureau des Longitudes was established as the ruling body for French astronomy and observatories were placed under its authority. The Bureau adopted Republican principles of equality among its members who included astronomers, instrument makers and navy officers. Among the astronomers of the Paris Observatory before the Revolution, however, only Cassini was nominated to the Bureau. Soon, scientist would be called by Napoleon to positions of power. Some observatory scientists would rise to the highest positions even if they had none of the qualities for that: Pierre-Simon Laplace was minister of the Navy for a few weeks (Serres 1997, Hahn 2005).

\section{The God Hypothesis: Laplace and Napoleon: The Three Meanings of Politics} As we see astronomy played a part in political debates at the time of the French Revolution. To discuss further the political nature of astronomy in nineteenth-century Paris, it may be useful to recall the various meanings politics may have. In the first sense, politics mingled

\footnotetext{
14 "Citoyens, il existe près de vous un établissement célèbre où l'on commande encore au nom des rois. Nous ne svenons pas vous demander le frapper de destruction : les nombreux volumes d'observations astronomiques et météorologiques [...] attestent assez de l'utilité de cet établissement. Nous vous demandons d'imprimer à ce monument les formes républicaines, et de substituer aux caprices du pouvoir les lois éternelles de l'égalité." Cf. Réimpression de l'Ancien Moniteur 17 (1858-1870), p. 542.
} 
with astronomical questions simply because astronomy was closely tied with political power, that is, in the time period we are looking at, to the State. The services it renders to the State are many: the calendar, the ephemerides, the astrological predictions, and the worldviews it put forward have often conspired to position astronomers close to the rulers. In Western Europe, governments set up imposing observatories in the seventeenth century. In the Enlightenment, the observatory became the seat of expertise that had a great value for imperial powers, especially in the realms of navigation and map making (Godlewska 1999). The nineteenth century witnessed the blossoming of the observatory sciences in this part of the world and its worldwide expansion (Aubin, Bigg et Sibum 2010).

Since astronomical work increasingly involved the collaboration of several people on a single project, the egalitarian utopias of the French Revolution rarely subsisted unscathed. On the contrary astronomy was most often hierarchically structured. This was especially true in centralized States like France where the hierarchical structure was national, but was also the case in England for example where the stature of the Astronomer Royal always set him apart for other members of the Royal Astronomical Society. National hierarchies as well as internal ones in the observatory gave rise to intense political debates and countless instances of bitter bickering that are well documented in the literature. ${ }^{15}$ This is the second sense in which I see astronomy as being eminently political.

In this paper, I would like to focus on the third sense in which astronomy was political, which is specific to the period in question. In this third sense, astronomy is political because it deals with the masses. It provides them with powerful worldviews that purport to say what the place of man is in the universe. It offers an image of the cosmic order which, I will try to show, is congruent with conceptions of the social order.

Let us recall the famous anecdote about the mathematician and astronomer Pierre-Simon Laplace finding he had no need for the God hypothesis. It was first made public by Dr. Francesco Antonmarchi, a medical doctor who joined Napoleon Bonaparte in exile on Saint Helen's. According to his recollections, the fallen emperor once teased him about the atheism he supposed characteristic of physicians.

One day, as he was arranging a bed of French beans, [Napoleon] perceived some small roots, and began a dissertation upon the phenomenon of vegetation. He analysed them, and descanted upon them with his usual sagacity, drawing from them the conclusion of the existence of a Superior Being who presides over the wonders of Nature. "You do not believe in all that, Doctor; you physicians are above those weaknesses. Tell me, you who are so well acquainted with the human frame, who have searched it in all its turnings and windings, have you ever met with the soul under your scalpel? Where does the soul reside? in what organ?" I hesitated to answer. "Come, be sincere; there is not a physician that believes in God, is there?" -

\footnotetext{
${ }^{15}$ Perhaps the most famous case is that of Le Verrier at the Paris Observatory from 1854 to 1877 with a twoyear gap between 1870 and 1872; on this see (Locher 2007).
} 
"No, Sire, they are seduced by the example; they imitate mathematicians." - "How so? Mathematicians are in general religious... However, your recrimination reminds me of a singular expression used by one of them. I was conversing with $\mathrm{L}-$; and, congratulating him upon a new work he had just published, I asked him how it happened that the name of God, so often used in the works of Lagrange, had never once occurred in his. 'It is,' answered he, 'because I have not found it necessary to have recourse to that hypothesis' (Antonmarchi 1829, vol. 1, p. 264-265).

First published in 1821, Antonmarchi's story, later embellished by Victor Hugo's prose, soon became a symbol of the way in which nineteenth-century science could dispense with God (Hugo 1987, 686). In the course of that century, astronomy was to take over from religion the task of providing a plausible account of the origin of the Universe which people could believe in (and Darwinian biology later offered an explanation for the origin of humans that perhaps proved less universally persuasive). As we know, this was no mean task, and debates have been raging since.

The first great atheistic natural philosophy was published in 1770 by the Baron d'Holbach. Immediately censored and greatly controversial, the Système de la nature was a passionate defense of materialistic philosophy denying that the soul could exist outside of the brain and that God was an anthropomorphic belief born in fear and lack of knowledge. Negating that matter and motion were created, this work however eschewed any serious consideration of cosmogonies. It had nothing to say about the origin of the cosmic order. Laplace's work, together with Kant's, introduced the nebulous hypothesis as the first explanation of the origin of the solar system which did not rely on a Creator. But Laplace's Système du monde was more powerful than d'Holbach's in that it simply doing away with the God hypothesis.

In 1884, the astronomer Hervé Faye, who was discretely Catholic, suggested an alternative interpretation of the episode which he said he held from François Arago (just like Hugo had claimed). According to Faye, Laplace could not have voiced such an opinion in front of the Emperor who would have rebuffed him; Laplace merely wished to dispense with a hypothesis used by Newton in the second edition of the Principia, where the natural philosopher has supposed that God intervened form time to time to insure the stability if the Solar system (Faye 1884, 110-111). ${ }^{16}$

In nineteenth-century France, the place of God in the new cosmologies was hotly debated. I have no time to discuss them here, but the number of publications that tried to accommodate recent discoveries in astronomy and the catholic religion still is little explored. I want to say that this is an extremely important terrain for investigating the cosmopolitics of this age. Interpreting the Heavens and providing a meaningful story about the origins of the cosmic order, as Faye emphasized in his book, indeed had only been one of the tasks assigned to religion. Although Faye was looking for an appeasement brought about by

\footnotetext{
${ }^{16}$ About Laplace's interest for Newton's hypothesis at the end of his life, see (Hahn, Pierre-Simon Laplace, 1749-1827: A Determined Scientist 2005, 201-203).
} 
science in "ardent philosphico-religious controversies," an appeasement that left room for the idea of God, the cosmic order he tried to popularize by allowing the possibility for extraterrestrial life and the end of the solar system was wholly different from previous religious orders. In the Old Regime, religion also provided the foundation of power, the absolute monarch being entrusted to lead his subjects by the grace of God. The role of religion had traditionally been to explain relations among all components of the universe (the gods, men, planets, animals, mountains, the seas, etc.). The social order was founded upon a higher type of order, one that was cosmic. In this sense, therefore, astronomy, politics and religion had always been interrelated.

\section{Arago at the "Rocher de Cancale": The Politics of Popularization}

The godless cosmic order needed its new priests. After the establishment of the Bureau des longitudes, the Parisian landscape for astronomy had changed greatly. Of the small dozen of active observatories active before the Revolution, only the Paris Observatory remained active. The astronomer Alfred Gautier from Geneva wrote:

There is now in Paris fewer active observatories and amateur astronomers than there was in the previous century. Political agitation, as well as the reversals of fortune and the institutional changes that come as consequences of this, must have contributed to this reduction $\left[\ldots . .{ }^{17}\right.$

If the number of active institutions for astronomy had decreased, opportunities to learn about the science had increased. Public astronomy lectures were given by Auguste Comte and François Arago, among others-and they proved hugely popular. There actually was among the attributions of the Bureau des longitudes an obligation of giving a course of astronomy. When François Arago joined the Bureau, he decided to teach this course at the Observatory and to teach a course of popular astronomy. Arago is an extremely important transitional character for the story I have in mind. He had a brilliant scientific and political career. He also was acclaimed as a brilliant popularizer.

In 1861, M. Pitre-Chevalier, a catholic journalist, director of the newspaper Le Figaro, told a story about that course that was ten to fifteen years old. ${ }^{18}$ Arago was chairing a dinner at the "Rocher de Cancale," rue Montorgueil, offered to the members of the Comité des gens de lettres. We know he was elected president in 1840 (Montagne 1988, 414). Among the 20 persons or more that were present, one recognized Victor Hugo and Honoré de Balzac. At the time, Arago was known in Paris for his great rhetorical skills for popularizing hard scientific questions to the wider public. His lessons on popular astronomy at the

\footnotetext{
17 “On doit convenir [...] qu'il y a maintenant à Paris moins d'observatoires en activité et d'amateurs d'astronomie qu'il n'y en avoit dans le siècle dernier. Les agitations politiques, ainsi que les renversemens de fortune et les changemens d'institutions qui en sont la suite, ont dû contribuer à cette diminution ; et les progrès même de l'astronomie rendent peut-être le rôle des observatoires secondaires moins important." (Gautier 1825, 204).

${ }^{18}$ The Preface of Arthur Mangin, Voyage scientifique autour de ma chambre; this text was reproduced in Le Musée des familles 29 (1861), 89-91.
} 
Observatoire were one of the great attractions for Bourgeois society. At this dinner, Arago explained that to make science accessible was one the highest missions of this century-and one of the easiest, too.

He exemplified what he was speaking of, by teaching us what we ignored or halfknew about a hundred things we had before us. A turbot introduced us to zoology and to the mysteries of Oceans; a salad to botanic and agriculture; a glass of champagne to industry and commerce; a Carcel lamp to mechanics and to the polarization of light; a fuming coffeemaker to the marvels of steam; an amber pipe to the miracles of electricity; a piece of coal to geology and mineralogy; a cup of coffee to chemistry and medicine; a billiard ball to physics and the theory of the worlds, etc., etc. etc. [sic]. ${ }^{19}$

This seemed simple enough, but the journalist was not convinced. To him, there was a contradiction between the skills needed from the scientist who had to be stern and boring and those needed to be "un homme d'esprit," a man of wit, who remained by nature an ignorant. Only Arago was able to bridge the two worlds. Joyful, the astronomer gave his secret:

In my first lesson, I choose among the audience the most vacuous face, the stupidest one, - a complete moron if I find one, - and I do not lose sight of him until the end of my lesson. To him I address my most complicated demonstrations. I start again and I repeat myself until his physiognomy lightens up and says: "I grasped it!" When the idiot has understood me, I am sure that I can be understood by anyone. And that's how I put science at the masses' reach. ${ }^{20}$

At this point a man entered the room and said to Arago:

Oh! Master! [...] What an honor to meet you here and to see you face to face! Surely you will recognize me! I am this assiduous listener of your lectures, at whom you

\footnotetext{
${ }^{19}$ "Il joignit l'exemple au precept, en nous enseignant tout ce que nous ignorions ou savions à demi, à propos de cent objets que nous avions sous les yeux. Un turbot nous initia de la sorte à la zoologie et aux mystères de la l'Océan ; une salade, à la botanique et à l'agriculture; un verre de champagne, à l'industrie et au commerce ; une lampe Carcel, à la mécanique et à la polarisation de la lumière; une cafetière fumante, aux merveilles de la vapeur ; une pipe d'ambre, aux miracles de l'électricité ; un morceau de charbon de terre, à la géologie et à la minéralogie ; une tasse de café, à la chimie et à la médecine; une boule de billard, à la physique et à la théorie des mondes, etc., etc., etc. " (p. 90).

${ }^{20}$ "Dès la première leçon, je choisis dans mon auditoire la figure la plus niaise, la plus stupide, — un crétin si j'en trouve un, - et je ne la quitte pas des yeux jusqu'à la fin de mon cours. C'est à lui que j'adresse les démonstrations les plus compliquées. Je les recommence et les répète jusqu'à ce que sa physionomie s'éclaire et le dise : " J'ai saisi la chose ! " Quand mon idiot m'a compris, je suis sûr d'être compris de tout le monde. Et voilà comment, je mets la science à la portée de la foule. » (p. 90)
} 
haven't stopped staring over the last month in the amphitheater of the Observatory! $!^{21}$

Whether this story is the accurate reflection of Arago's opinions or a fanciful anecdote embellished by the journalist, I believe that this account can be enlightening to us. Popularization of science is often taken at face value, as a laudable enterprise for the diffusion of knowledge. We are so much accustomed to the thought that this is an obviously good thing that in the extensive production on science popularizers in the nineteenth century historians have rarely pause to ponder the goals pursued by them. ${ }^{22}$ Was the patronizing that lays at the heart of this story the flipside of the first attempts at massive popularization of science?

\section{Blanqui in Jail, Communards in the Observatory: Order and the Public Participation in Science}

Auguste Blanqui (1805-1881) is well known as one of the most committed revolutionaries of nineteenth-century France, having spent several of his years in jail. In 1870, he was imprisoned again for having conspired against the nascent Republic of Adolphe Thiers. While incarcerated, Blanqui wrote a unusual tract called Eternity by the Stars [L'éternité par les astres]. In this remarkable booklet, Blanqui drew radical consequences that he thought were the logical conclusion of recent advances in science:

What I am presently writing in my cell of the fort of Taureau, I have written it and I will write it again in all eternity, at a similar table, with a similar pen, under similar clothes, in similar circumstances. And so, for each of us. ${ }^{23}$

After the bloody failure of the Paris Commune, the "astronomical hypothesis" might have offered a ray of hope to the old revolutionary. To my purpose, this text is remarkable because it resorts to astronomy to suggest a pacific resolution of close to a century of political violence. To design the resolution, Blanqui deftly used the most recent scientific advances such as spectroscopy which had emerged over the last ten years. Clearly, Blanqui was well informed of active areas of research, perhaps by followers of Arago as science popularizers. This astronomical vision of society appears as the gospel of a new age. It also indicated that the astronomical sky was for the common people to reclaim as its own.

Back on earth, the decade of the 1870s witnessed great movements among the Paris astronomical community and the Paris Observatory had once again been under attack by

\footnotetext{
${ }^{21}$ « Ah ! maître, s'écria-t-il, quel honneur pour moi de vous rencontrer ici et de vous contempler face à face! Vous me reconnaissez sans doute ! je suis cet auditeur assidu de vos cours, que vous ne quittez pas des yeux depuis un mois à l'amphithéâtre de l'Observatoire!"

${ }^{22}$ The littérature here is important, but let us mention : (Raichvarg et Jacques 1991, Bensaude-Vincent et Rasmussen 1997, Daum 2002)

${ }^{23}$ "Ce que j'écris en ce moment dans un cachot du fort du Taureau, je l'ai écrit et je l'écrirai pendant l'éternité, sur une table, avec une plume, sous des habits, dans des circonstances toutes semblables. Ainsi de chacun. " (Blanqui 1872). Although it was cited by Borges and Benjamin, there are still no definitive study of this booklet; for a viewpoint from literary criticism, see however (Hamel 2000).
} 
revolutionaries. After a long fight against Arago's successor Urbain Le Verrier, Charles Eugène Delaunay directed the Paris Observatory for two short years only (Thévenot 1878). On 5 August 1872, Delaunay's body was found on rocks near Cherbourg after his boat capsized. Manuscript notes were found in his pockets detailing what happened during the last hours of the Paris Commune uprising, during which Delaunay had remained in the Observatory. When war was declared in July 1870, Delaunay protected all instruments. At the armistice, he had the instruments reinstalled under the cupola. When the Republic was proclaimed on 4 September 1870, Delaunay served as president of a scientific committee established to defend the country. But when the Commune was declared, Delaunay put up the red flag on the Observatory. Most astronomers gone, Delaunay found himself alone with the American astronomer Simon Newcomb working in the library (Newcomb 1903).

On May 22, with Republican troops entering the city, near the Trocadero, barricades are set up around the Observatory. Asked to deliver spyglasses to the Communards, Delaunay showed them the meridian telescope weighing several hundred kilos and an equatorial telescope roughly $20 \mathrm{~m}$-long, keeping smaller ones hidden. The next day at noon, the Observatory is attacked and taken by the rebels. They fire on the advancing troops from the top of the Observatory. Around midnight, they flee after having started a fire in an office. On May 24, the rebels come back, angry that the fire was put out. The Observatory and its gardens would be free from fighting only on Friday 26 May. Delaunay leaves Paris to regroup with his family (Thévenot 1878, 117-118, Vidieu 1876, 472).

That Delaunay kept those handwritten notes in his wallet is significant. This episode had left a mark on him. In 1872, the Republican organization of astronomy in France was hotly debated. New observatories were set up in the provinces but their status with respect to the Paris Observatory and the Bureau des longitudes was up for grab (Boistel 2005, Delanoé et Soubiran 2011). Attacks fused in the press (Le Siècle, 20 June 1872). In a letter, Delaunay replied:

You have no idea of the state in which I found the personnel of the Observatory whan I arrived [...]. I had to put order into it; the majority of the personnel went back to work with ardor and faith. But the Observatory has its Communards like society, and those have no tolerance for calm. [...] The Commune of the Observatory has reached the time of the great fire; it will in no time be reduced to oblivion like was the Commune of Paris. ${ }^{24}$

This debate comes back to issues of power relation within the Observatory or among the astronomical community (Saint-Martin 2007). This issue has become crucial with the

\footnotetext{
${ }^{24}$ «Vous pouvez vous faire une idée de l'état où j'ai trouvé le personnel de l'Observatoire, lorsque j'y suis entré. (...) J'ai dû chercher à rétablir l'ordre ; la majorité des fonctionnaires s'est remise au travail avec ardeur et confiance. Mais l'Observatoire a ses communards comme la société, et ceux-là n'admettent pas le calme [...]. La Commune de l'Observatoire en est à sa période d'incendies; elle ne tardera pas à être réduite au néant comme l'a été celle de Paris. " (Thévenot 1878, 126).
} 
development of observatory techniques. The British Astronomer Royal George Biddell Airy insisted: "Astronomy is pre-eminently the science of order" (Airy 1858, viii). Similarly, Le Verrier when he became director of the Paris Observatory in 1854, has seen as his first task to reform the work regimen there. It is interesting to underline that the fear of "anarchy" determined the political understanding of the astronomical worker (Aubin 2003).

There is a contradictory tension in the history of nineteenth-century astronomy. On the one hand, the rhetoric and actuality of public service tied the observatory with the State and society ever more intensely. On the other hand, the development of heavy instrumentation (whose payment by the State was made possible in the first because of the services rendered by astronomy) led astronomers to wish for peace. But I would like to say that this tension goes further: as I have already hinted at, the issue here was who is in and who is out. As Blanqui's essays exemplified, popularization had become insufficient as response. Public participation in science, the kind that Hirzing had in mind when praising astronomical cosmopolitanism, needed to be developed. A revealing instance of this is the story of the Popular Observatory at the Trocadero. Its founder Léon Jaubert was an instrument maker. His success highlights the very wide public appeal of astronomical observation in the last quarter of the century, his difficulties the fact that regulating public participation was of tremendous importance. ${ }^{25}$

\section{Conclusion}

Astronomy was the science of the nineteenth century for the same reasons that Paris was its capital, as Walter Benjamin would have it. The convulsion brought about by revolution, industrialization and the rise of the bourgeoisie were mirrored in debates about astronomical politics and political astronomy. Astronomy in nineteenth-century Paris (and presumably much beyond it) was political not only because of hierarchical fights and the tight link it had with the State and government; it was political because it offered it was about to become the foundation of the mainstream opinion about the cosmic order.

Fights within the astronomical community seemed to be mostly about trivial points: the inner organization of the observatory, research agendas, etc. But they are the reflection of deeper conflicts. In such fight, the State often served as the arbiter. It was drawn to this role because it found itself dependent on the expert knowledge astronomers offered in the domains of navigation, cartography or meteorology. Encounters between astronomers and a larger public often seem to be based on misunderstandings, but, here again, they reflect deeper issues. They were about the role the people would be allowed to play in the construction of a new cosmic order and thereby about their role in the new social/political order. Whether and to what extent astronomy itself was democratic can be understood as the litmus test for the new order. In these debates, religion played a much more prominent role than previously considered. This role needs to be studied more closely, but it seems to

\footnotetext{
${ }^{25}$ Another revealing case was the Berlin Urania (Molvig 2010).
} 
me that the religious concerns about modern astronomy and cosmology are a great battle ground to study the great anthropological shift in nineteenth-century cosmopolitics.

\section{Bibliographie}

Airy, George Biddell. Six Lectures on Astronomy. London, 1858.

Alder, Ken. The Measure of All Things: The Seven-Year Odyssey and Hidden Error that Transformed the World. New York: Free Press, 2002.

Antonmarchi, Francesco. The Last Days of Napoleon: Memoirs of the last two years of Napoleon's exile, forming a sequel to the Journals of Dr. O'Meara and Count Las Cases. 2nd ed. 2 vols. London: Henry Colburn, 1829.

Aubin, David. "Observatory Mathematics in the Nineteenth Century.» Dans Oxford Handbook of the History of Mathematics, de Eleanor Robson et Jackie Stedal, 273-298. Oxford: Oxford University Press, 2009.

Aubin, David. «The Fading Star of the Paris Observatory in the Nineteenth Century: Astronomers' Urban Culture of Circulation and Observation.» Osiris 18 (2003): 79-100.

Aubin, David, Charlotte Bigg, et H. Otto Sibum, . The Heavens on Earth: observatories and astronomy in nineteenth-century science and culture. Durham: Duke University Press, 2010.

Bensaude-Vincent, Bernadette, et Anne Rasmussen, . La Science populaire dans la presse et l'édition, 19e et 20e siècles. Paris: CNRS, 1997.

Blanqui, Louis Auguste. L'Éternité par les astres: hypothèse astronomique. Paris: Librairie Germer Baillière, 1872.

Boistel, Guy. Observatoires et patrimoine astronomiue français. Paris: ENS éditions; Cahiers d'histoire et de philosophie des sciences, 2005.

Buchwald, Jed Z., et Diane Greco Josefowicz. The Zodiac of Paris: How an Improbable Controversy over an Ancient Egyptian Artifact Provoked a Modern Debate between Religion and Science. Princeton: Princeton University Press, 2010.

Burstin, Haim. L'invention du sans-culotte: regards sur le Paris révolutionnaire. Paris: Odile Jacob, 2005.

Cassini, Jean-Dominique. Mémoires pour servir à l'histoire des sciences et à celle de l'Observatoire royal de Paris, suivis de la vie de J.-D. Cassini écrite par lui-même et des éloges de plusiers académiciens morts pendant la Révolution. Paris: Bleuet, 1810.

Chapin, Seymour L. «The Vicissitudes of a Scientific Institution: A Decade of Change at the Paris Observatory.» Journal for the History of Astronomy 21 (1990): 235-274. 
Daum, Andreas. Wissenschaftspopularisierung im 19. Jahrhundert: bürgerliche Kultur, naturwissenschaftliche Bildung und die deutsche Öffentlichkeit, 1848-1914. 2nd. Munich: Oldenburg, 2002.

Decremps, Henri. La Science sansculotisée, premier essai sur les moyens de faciliter l'étude de I'Astronomie, tant aux amateurs et aux gens de lettres, qu'aux marins de la République française, et d'opérer une Révolution dans l'enseignement. Paris, 1792.

Delanoé, Jérôme, et Caroline Soubiran. La (re)fondation des observatoires astronomiques sous la Ille République : Histoire contextuelle et perspectives actuelles. Bordeaux: Presses universitaires de Bordeaux, 2011.

Dumont, Simone, et Suzanne Debarbat. «Fouchy et ses travaux en astronomie.» Revue d'histoire des sciences 61 (2008): 23-39.

Faye, Hervé. L'Origine du monde: théories cosmogoniques des anciens et des modernes . Paris: Gauthier-Villars, 1884.

Gautier, Alfred. Coup d'oeil sur l'état actuel de l'astronomie en France et en Angleterre. Genève: imprimerie de la Bibliothèque universelle, 1825.

Godelier, Maurice. Au fondement des sociétés humaines : ce que nous apprend l'anthropologie. Paris: Albin Michel, 2007.

Godlewska, Anne. Geography Unbound: French Geographic Science from Cassini to Humboldt. Chicago: University of Chicago Press, 1999.

Hahn, Roger. "Les observatoires en France au XVIIle siècle.» Dans Enseignement et diffusion des sciences en France au XVIIle siècle, de René Taton, 654. Paris: Hermann, 1986.

-. Pierre-Simon Laplace, 1749-1827: A Determined Scientist . Cambridge: Harvard University Press, 2005.

Hamel, François. «"Rien de nouveau sous les soleils". Répétition et origine de l'histoire dans L’Éternité par les astres de Blanqui.» Protée, 2000: 45-58.

Hirzel, Gaspard. Astronomie de l'amateur, ou considération philosphiques et populaires sur l'univers, suivies d'une méthode nouvelle et facile de connoître les étoiles. Geneva: J. J. Paschoud, 1820.

Hugo, Victor. «Choses vues (1887).» Dans Histoire. Paris: Robert Laffont, Bouquins, 1987.

Lalande, Jérôme. "Histoire de l'aastronomie en 1794, année seconde de la République française.» Magazin encyclopédique, ou Journal des sciences, des lettres et des arts 1 (1795): 1-35.

Locher, Fabien. "L'empire de l'astronome : Urbain Le Verrier, l'Ordre et le Pouvoir.» Cahiers d'histoire, 2007: 22-48.

Marejko, Jan. Cosmologie et politique. Pars: L'Âge de l'homme, 1989.

Mercier, Louis-Sébastien. Tableau de Paris. Amsterdam, 1789. 
Merleau-Ponty, Jacques. La Science de l'univers à l'âge du positivisme: étude sur les origines de la cosmologie contemporaine. Paris: Vrin, 1983.

Merleau-Ponty, Jacques. "Situtation et rôle de l'hypothèse cosmogonique dans la pensée cosmologique de Laplace.» Revue d'histoire des sciences 29 (1976): 21-49.

Molvig, Ole. "The Berlin Urania, Humboldtian Cosmology, and the Public.» Dans The Heavens on Earth: Observatories and Astronomy in Nineteenth-Century Science and Culture, de David Aubin, Charlotte Bigg et H. Otto Sibum, 325-343. Durham: Duke University Press, 2010.

Montagne, Édouard. Histoire de la société des gens de lettres de France. Paris: Société des gens de lettres de France, 1988.

Montucla, Jean-Étienne de. Hsitoire des mathématique. Édité par Jérôme Lalande. Vol. 4. Paris: henri Agasse, 1802.

Newcomb, Simon. The Reminiscences of an Astronomer . Boston: Houghton Mifflin, 1903.

Perny, J. de. Le Guide astronomique, ou calendrier à l'usage des astronomes et des amateurs de I'astronomie. Paris, 1791.

Raichvarg, Daniel, et Jean Jacques. Savants et ignorants : une histoire de la vulgarisation des sciences. Paris: Seuil, 1991.

S.-Devic, M.J. F. Histoire de la vie et des travaux scientifiques et littéraires de J[ean]-D[ominique] Cassini IV . Clermont, Oise: Alexandre Daix, 1851.

Saint-Martin, Arnaud. «Une constitution pour l'astronomie française au tournant du siècle. Sociogenèse d'un champ scientifique.» Cahiers d'histoire, 2007: 49-63.

Sarda, François. Les Arago: François et les autres. Paris: Tallandier, 2002.

Serres, Michel. «Paris 1800.» Dans Éléments d'histoire des sciences, de Michel Serres. Paris: Larousse, 1997.

Thévenot, Arsène. Charles-Eugène Delaunay, Membre de l'Institut, Directeur de l'Observatoire de Paris (1816-1872). . Troyes: Dufour-Bouquot. , 1878.

Vidieu, Auguste. Histoire de la commune de Paris en 1871. Paris: E. Dentu, 1876.

Wolf, C. Histoire de l'Observatoire de Paris de sa fondation à 1793. Paris: Gauthier-Villars, 1902. 